\title{
A G-to-A single nucleotide polymorphism in intron 2 of the human CACNA2D2 gene that maps at 3p21.3
}

\author{
D. Angeloni, ${ }^{1 *}$ F.-M. Duh, ${ }^{2}$ M.-H. Wei, ${ }^{2}+$ B. E. Johnson ${ }^{3}$ and M. I. Lerman ${ }^{1}$ \\ ${ }^{1}$ Laboratory of Immunobiology, National Cancer Institute - Frederick Cancer Research \\ and Development Center. Frederick, MD 21702-1201, USA, ${ }^{2}$ Intramural Research \\ Support Program, SAIC, Frederick Cancer Research and Development Center, \\ Frederick, MD 21702-1201, USA, ${ }^{3}$ Dana-Farber Cancer Institute, Boston, \\ MA 02115, USA.
}

(Received 25 September 2000, Accepted 18 December 2000)

KEYWORDS: CACNA2D2, loss of heterozygosity (LOH), lung cancer, single nucleotide polymorphism (SNP).

\section{SOURCE/DESCRIPTION}

A single nucleotide polymorphism (SNP) was found in intron 2 of the human Alpha 2 Delta calcium channel subunit 2 gene (CACNA2D2, GenBank acc. AF042792) by single strand conformational polymorphism (SSCP) method, during mutation analysis of normal/tumor paired DNA samples obtained from small-cell lung cancer patients. ${ }^{1,2}$ The Alpha 2 Delta 2 gene maps at 3p21.3, in the region that most frequently undergoes loss of heterozygosity $(\mathrm{LOH})$ in lung cancer. The polymorphism consists of a G-to-A transition (Fig. 1(b)) and is located on cosmid LUCA 9 (residue 2208, GenBank acc. Z75743). The allele ' $A$ ' has an index of heterozygosity of 33\% among small-cell lung cancer patients. This SNP is informative with regard to $\mathrm{LOH}$ investigation in cancer patients (Fig. 1(a)). No biased loss of one allele over the other was observed. Since no data are available on the ethnic background of the patients tested, $\mathrm{CEPH}^{3}$ individuals were used as control. Among them, the allele ' $A$ ' has an index of heterozygosity of $22 \%$. The G-to-A transition eliminates a Ddel restriction site from the 115-bp PCR product obtained with the following primers.

\section{PRIMERS SEQUENCE}

Lu9 2Fw: 5' GTC TCC TCT TTG GAC AGA TTC TG

Lu9 2Rv: 5' TGG AGA TGA CTG TAA CAA GGG CAC

\section{PCR-SSCP ANALYSIS}

The radioactive reaction was performed in a total reaction volume of $12 \cdot 5 \mu \mathrm{l}$, containing $100 \mathrm{ng}$ of genomic DNA, $12.5 \mathrm{pmol}$ of each primer, $200 \mu \mathrm{M}$ dNTPs, $1.5 \mathrm{mM} \mathrm{MgCl}_{2}, 1.25 \mathrm{nCi} \alpha 35 \mathrm{~S}$-dATP. Primers amplify a single product under the following cycling conditions: $3 \mathrm{~min}$ at $95^{\circ} \mathrm{C} ; 35 \times\left(1 \mathrm{~min}\right.$ at $95^{\circ} \mathrm{C}, 30 \mathrm{~s}$ at $64^{\circ} \mathrm{C}, 1 \mathrm{~min}$ at $\left.72^{\circ} \mathrm{C}\right) ; 7 \mathrm{~min}$ at $72^{\circ} \mathrm{C}$. After heat

\footnotetext{
* Author to whom all correspondence should be addressed at: Laboratory of Immunobiology, National Cancer Institute - Frederick Cancer Research and Development Center. Frederick, MD 21702-1201, USA: Tel: +301 846 1288; Fax: +301 846 6145; E-mail: andreazzolid@mail.ncifcrf.gov

+ Present address: Celera Genomics Corporation, Rockville, MD, USA.
} 
Patient 1 Patient 2 Patient 3

Bl. T. Bl. T. Bl. T.

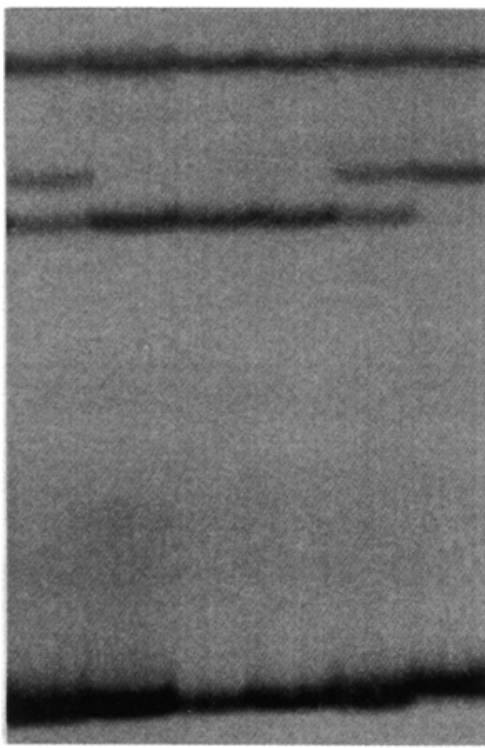

(a)
$\begin{array}{llll}\mathbf{A} & \mathbf{A} & \mathbf{T} & \mathbf{C}\end{array}$

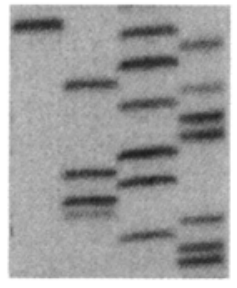

Allele "A"

$\begin{array}{lllll}\mathbf{G} & \mathbf{A} & \mathbf{T} & \mathbf{C}\end{array}$

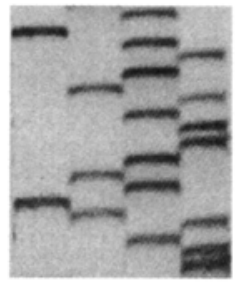

Allele "G"

(b)

Fig. 1. Mutation analysis of the CACNA2D2 gene in small cell lung cancer patients, by means of Lu9 2Fw-2Rv primers, revealed the presence of a SNP located in intron 2. (a) SSCP profile of three different patients. Allele ' $A$ ' gives the upper band, allele ' $\mathrm{G}^{\prime}$ gives the lower band (sequence in (b)). B1, DNA extracted from blood; T, DNA extracted from tumor. This heterozygous marker is a diagnostic tool of $\mathrm{LOH}$ in lung cancer patients.

denaturation $\left(8 \mathrm{~min}\right.$ at $90^{\circ} \mathrm{C}$ ) in formamide buffer (Stop Solution, Amersham, Arlington Heights, IL, USA), PCR products (115 bp) were run overnight in a $0.5 \times \mathrm{MDE}$ gel (FMC Bioproducts, Rockland ME), $0.6 \times \mathrm{TBE}$, at room temperature, $8 \mathrm{~W}$ constant power; transferred on $3 \mathrm{MM}$ paper, dried and exposed to autoradiography film (X-OMAT AR, Kodak, Rochester, NY, USA).

\section{SEQUENCING}

Sequencing reactions were done either manually (T7 Sequenase Kit, Amersham, Arlington Heights, IL, USA) or automatically (ABI 373 Stretch Automated DNA Sequencer, Applied Biosystems, Foster City, CA, USA).

\section{FREQUENCY}

In total, 21 pairs of normal/tumor DNA, obtained from lung cancer patients, were analysed. Nine individuals (paired samples number: 8066/866, 5297/5301, 43/ 5322, 7161/6395, 5305/5310, 8362/8364, 7995/ 10213, 930/825, Bl1/H128, affected with small cell lung cancer), were found heterozygous for the allele ' $A$ ' (Fig. 1). The polymorphic allele was found in eight $\mathrm{CEPH}^{3}$ control individuals $(1349-01 ; 23-02 ; 35-02$; 1345-01, homozygous; $1424-02$; 28-01; 1355-01; 1447-01) out of 36 analysed. The allele ' $A$ ' index of heterozygosity corresponds to $33 \%$ among small cell lung cancer patients, and to $22 \%$ in the $\mathrm{CEPH}$ control population.

\section{ACKNOWLEDGEMENTS}

Many thanks to David I. Sommers for great discussion. This project has been funded in toto with Federal funds from the National Cancer Institute, National Institutes of Health, under Contract No. NO1-CO-56000. The content of the publication does not necessarily reflect the views or policies of the Department of Health and Human Services, nor does mention of trade names, commercial products, or organizations imply endorsement by the US Government.

\section{REFERENCES}

1. Johnson, B. E., Makuch, R. W., Simmons, A. D., Gazdar, A. F., Burch, D., Cashell, A.W. (1988). myc family DNA amplification in small cell lung cancer patients' tumors 
and corresponding cell lines. Cancer Research 48, 5163-6.

2. Phelps, R. M., Johnson, B. E., Ihde, D. C., Gazdar, A. F., Carbone, D. P., McClintock, P. R. et al. (1996). NClNavy Medical Oncology Branch cell line data base. Journal of Cellular Biochemistry Suppl 24, 32-91.
3. Dausset, J., Cann, H., Cohen, D., Lathrop, M., Lalouel, J. M., White, R. (1990). Centre d'etude du polymorphisme humain $(\mathrm{CEPH})$ : collaborative genetic mapping of the human genome. Genomics 6, 575-7. 